\title{
Using Fun English Learning for Trauma Healing of the Earthquake Victim Students
}

\author{
Devia Nur* \\ Postgraduate English Study Program \\ Universitas Mataram \\ Mataram, Indonesia \\ devianur2806@gmail.com
}

\author{
Kamaluddin Yusra \\ Postgraduate English Study Program \\ Universitas Mataram \\ Mataram, Indonesia \\ kamaludin@unram.ac.id
}

\author{
Amrullah Amrullah \\ English Department Study Program \\ Universitas Mataram \\ Mataram, Indonesia \\ amrullah@unram.ac.id
}

\begin{abstract}
This paper discus about the use of Fun English Learning to heal the trauma of the earthquake victims' students in Lombok and this is the second phase of the first successful treatment. This study is a mixed-method in nature as it uses pseudo/quasi experimental method. The data were collected by using pre-and-post questionnaires with a series of treatment for post-traumatic experiences with interactive and communicative fun English learning. The data were analyzed using the following procedure: identifying English learning strategies, identifying the pre and post treatment scores, scoring up the total scores of the students, classifying the data into Acute Stress Disorder and Post Trauma Stress Disorder based on the stress Questionnaire scores. The study found numerous strategies for fun English Learning best used for trauma healing and these strategies have successfully introduced fun and communicative skills to the earthquake victim students but also healed the trauma.
\end{abstract}

Keywords-online materials, oral and written English skills

\section{INTRODUCTION}

The series of earthquakes occurred in Lombok Island, West Nusa Tenggara in the end of July until August 2018 brought a huge impact in every sector of life to the people on Lombok Island. Lombok Island was hit by a series of the Earthquakes with the extreme of magnitude. On Sunday July 29, 2018 a 6.4 magnitude quake trigged landslide in the mountain region of the island in East Lombok. The second Earthquake was on Sunday August 5, 2018 a 6.9 magnitude Earthquake hit Lombok overnight, and was followed by a number of aftershocks for many times between magnitude 5.4-6.5 in different epicentre in which people died, home were destroyed, education was affected within this event the schools were closed at the moment. As a result, the students had to deal with this situation beyond their understanding. To play the important role as a teacher who has to support the students in the grey areas of the emotional situation. Read and Ross [1] state that the life events that could lead to trauma include physical and sexual abuse, neglect, family violence and chaos, military combat, death of primary caretakers, war and imprisonment. In relation to problems associated with trauma, the key diagnostic classification is Post Traumatic Stress Disorder (PTSD).

The disaster trauma affected the students and it is evident that emotional instabilities, such as Post Traumatic Stress Disorder (PTSD), has a negative effect on students' academic abilities through attention and concentration lapses brought on by anxiety and distress. Research on disaster trauma in areas such as those affected by hurricanes, earthquakes and war has shown the effect student-teacher relationships has on the mental healing of the students and the many facets that are involved [2].
SMAN 1 Gunungsari was one of the Senior High Schools in Lombok which was affected by the Earthquakes that can be seen from the effect of the Earthquake. My observation of the school shows that from 29 rooms there were only 4 rooms that were safe to be used for teaching and learning process. The students and teachers were back to the teaching and learning process after a month of unconducive situation. A number of participants in SMAN 1 Gunungsari were affected, they lost their homes, people they love and, they were traumatised by the Earthquakes. Cutting [3] expresses that it is important to investigate the influence of trauma, because an overwhelming traumatic event cannot be fully and meaningfully processed by the human brain without proper intervention and assistance. Due to the high level of arousal and elevations of stress hormones accompanying such events, traumatic memories can become more deeply engrained in neural pathways than ordinary memories. This greatly increases the probability that a traumatic event, although it belongs to the past, will continue to have an influence on an individual [4].

The students at SMAN 1 Gunungsari experienced the disaster and they were traumatised. This condition affected the teaching and learning process that it was not running well at the moment. The condition of the students traumatised of the Earthquake made the teaching and learning process unconducive. Some conditions like this can be potentially traumatic, and the events include disaster, victims of crime, loss of the loved ones (family, relative, etc,), and loss properties [5].

This is the second phase of the first successful treatment with Fun English Learning best used for trauma healing and these strategies have successfully introduced fun and communicative skills to the earthquake victim students but also healed the trauma. The aim of Fun English Learning is to put the joyful and comfortable atmosphere in the classroom in order to make student feel comfortable and enjoy the teaching and learning process. This atmosphere of learning can help the student to heal the trauma. Steele [6] Neuroimaging studies and measurement of brain chemical transmitters reveal that students' comfort level can influence information transmission and storage in the brain. When the students are engaged, motivated and feel minimal stress, information flows freely through the affective filter in the brain. Heller [7] have proposed that students retain what they learn when the learning is associated with strong positive emotion. Using Fun English Learning as an alternative of trauma healing for the student could be considered as the best way since it contains a joyful learning process. Furthermore, 
it is a precious resource not only to heal the trauma to do the teaching and learning process effectively.

Fun English Learning will be applied in this second phase of study, in order to heal the trauma and to make communicative learning process. As this study has not been done by another before the first phase, it is interesting to continue the study in this second phase. in order to give the student trauma healing through Neuro Linguistic programming VAK (Visual, Auditory and Kinaesthetic) by using Game, Song, and joyful activities in the classroom in hope that Fun English Learning can bring the Joyful atmosphere and heal the trauma of the student step by step to make the communicative learning efficient. Hence, I would like to do the second phase of study about "Using Fun English Learning for Trauma Healing of the Earthquake student victims.

\section{METHOD}

This study is a mixed-method in nature as it uses pseudo/quasi experimental method. The Subject of this study were the student victims at SMAN 1 Gunungsari. The data were collected by using pre-and-post questionnaires with a series of treatment for post-traumatic experiences with interactive and communicative fun English learning. The data were analyzed by using the following procedure: identifying English learning strategies, identifying the pre and post treatment scores, scoring up the total scores of the students, classifying the data into Acute Stress Disorder and Post Trauma Stress Disorder based on the stress Questionnaire scores.

\section{RESULTS AND DISCUSSION}

There ware a lot of data collected from questionnaires and interview as the research finding which help us to answer the research questions.

\section{A. The type of fun English Learning}

The type of fun English Learning is divided into 3 types of learning style which are Visual, Auditory and Kinesthetic.

TABLE 1. STUdENTS' LEARNING STYLE

\begin{tabular}{cccc}
\hline No. & Leaning Style & F (students) & \% \\
\hline 1. & Visual & 14 & $64 \%$ \\
2. & Auditory & 4 & $18 \%$ \\
3. & Kinesthetic & 14 & $18 \%$ \\
4. & Total & 22 & $100 \%$ \\
\hline
\end{tabular}

From the data collection, there are 14 students with the biggest percentage $64 \%$ whose visual learners, 4 students are visual learners, and 4 students are kinaesthetic learners. From 22 students the visual learners are dominant in the classroom

Students' Learning style and teaching strategy should be related. While I was conducting the data I used 10 strategies in the teaching and learning process that related with the students' learning style such as; the use of pictures, the use of auditory-musical, the use of physical (kinaesthetic), opening the class with interactive words, the use of giving point and stars on the students' projects, reflection, the use of hangman game, the use of race game and guessing game strategies. Brown [8] defines learning styles as the manner in which individuals perceive and process information in learning situations. He argues that learning style preference is one aspect of learning style, and refers to the choice of one learning situation or condition over another

To find out that the 10 strategies is fun and communicative or not it can be seen from the students' perspective in their answers on the questionnaires and interview about the 10 strategies, from 22 students most of their answers are very preferable and preferable for the 10 strategies that was applied by me, that means the 10 strategies is Fun and communicative for them most of the students said in the interview that the 10 strategies help them understand the materials easier, make them interested to learn more lebih buat kita mudah mengerti (make us easier to understand), ndak bikin ngantuk (the materials do not make us sleepy). Celcia-Murcia [9] defines learning styles as the general approaches-for example, global or analytic, auditory or visual - that students use in acquiring a new language or in learning any other subject. The manner in which a learner perceives, interacts with, and responds to the learning environment. from the data observation, interview and questionnaire the students were enjoying the class, interactive and respond the learning atmosphere with joy. The students were very active and understood the materials very well. In term of trauma healing, the learning style should be one of the most important components. In order to achieve the ultimate goal of student learning it is important to use a combination of teaching methods and to make the classroom environment as stimulating and interactive as possible. Students learn in many different ways. Some students are visual learners, while others are auditory or kinesthetic learners. Visual learners learn visually by means of charts, graphs, and pictures. Auditory learners learn by listening to lectures and reading.

Kinesthetic learners learn by doing. Students can prefer one, two, or three learning styles. Because of these different learning styles, it is important for teachers to incorporate in their curriculum activities related to each of these learning styles so that all students are able to succeed in their classes. While we use all of our senses to take in information, we each seem to have preferences in how we learn best. In order to help the students, learn, we need to teach to as many of these preferences as possible, the various inventories on learning styles allow teachers to gain insight into which areas they can use further development in and which are already well developed [10].

\section{B. Use of Fun English Learning Effective to Heal the Trauma Related to Disaster}

The research that had been done by me indicated that Fun English Leaning is effective to heal the trauma of the students. It could be seen from the research finding that showed us the decreasing of the students' score from the pre-treatment questionnaire and post-treatment questionnaire. 
TABLE 2. THE SCORE RESULTS FOR THE PRE AND POST TREATMENT TRAUMA HEALING QUESTIONNAIRE.

\begin{tabular}{cccc}
\hline $\begin{array}{c}\text { Students } \\
\text { initial name }\end{array}$ & $\begin{array}{c}\text { Pre-test } \\
\text { score }\end{array}$ & $\begin{array}{c}\text { Post-test } \\
\text { score }\end{array}$ & Conclusion \\
\hline AGU & 55 & 25 & Healed \\
ASB & 32 & 30 & Healed \\
AMN & 6 & 6 & Healed \\
BHA & 72 & 38 & Healed \\
CNI & 12 & 5 & Healed \\
EW & 27 & 14 & Healed \\
EM & 55 & 26 & Healed \\
GLH & 78 & 49 & Healed \\
HE & 46 & 11 & Healed \\
IQ & 46 & 34 & Healed \\
KNAK & 64 & 42 & Healed \\
LSH & 54 & 34 & Healed \\
MH & 71 & 42 & Healed \\
MY & 56 & 14 & Healed \\
MSH & 60 & 29 & Healed \\
MA & 27 & 15 & Healed \\
NCR & 27 & 20 & Healed \\
RN & 39 & 14 & Healed \\
RK & 44 & 28 & Healed \\
ROK & 60 & 37 & Healed \\
SN & 62 & 42 & ASD \\
Z & 37 & 13 & \\
SUM & 1030 & 556 & \\
MEAN & 46.82 & 25.77 & \\
\hline & & & \\
\hline
\end{tabular}

Table 2. Shows the score results for the pre and post treatment trauma healing questionnaire shows that the mean score of pre-treatment questionnaire is 46.82 and the mean score of the post-treatment is 25.77 . That means the trauma score of the students' decrease. There are 95, 5\% (21 students) whose healed and $4.5 \%$ (1 student) whose unhealed or still have acute stress disorder, from this result, it can be concluded that the Fun English Learning worked effectively to heal the trauma of the students, from 22 students only 1 student who still have ASD. Similar with the related study entitled the effectiveness of trauma healing methods to reduce Post-Traumatic Stress Disorder (PTSD) on teenage victims of Mount Merapi eruption, and "Trauma Healing Oleh Muhammadyah Disaster Management Center Untuk Anak Korban Bencana (Studi Kasus Bencana Tanah Longsor di Desa Sampang, Kecamatam Karangkobar, Banjarnegara, Jawa Tengah [11]. Successful in their research about trauma healing with different method they got the good result.

Hence, it could be concluded that the result of the research showed that there are 3 types of learning styles and 10 strategies that consist on Fun English learning. The Fun English leaning is effective to heal the trauma related to disaster and also make the atmosphere of a communicative learning environment. It could be seen from the data in the research finding, the students' perspective about Fun English Leaning also about the decrease trauma score from the pre-treatment and the post-treatment score. Another could be seen from the data documentation the students were happy and enjoy the Fun English Learning.

\section{CONCLUSION}

From the study, it can be concluded that: The first, there were three types of students' learning styles which are Visual, Auditory and Kinaesthetic, and 10 strategies in the teaching and learning process that related with the students' learning style. The second, 10 strategies are very preferable to be a communicative learning process. The third, it shows that the mean score of pre-treatment questionnaire is 46.82 and the mean score of the post-treatment is 25.77 . It means the trauma score of the students' decrease. The fourth, it can be concluded that the Fun English Learning worked effectively to heal the trauma of the students, from 22 students only 1 student who still have ASD. Thus, the use of Fun English Learning is effective to heal the trauma related to disaster and make the students encouraged their communicative skills.

\section{REFERENCES}

[1] J. Read and C. A. Ross, "Psychological trauma and psychosis: Another reason why people diagnosed schizophrenic must be offered psychological therapies," in Journal of the American Academy of Psychoanalysis, 2003, doi: 10.1521/jaap.31.1.247.21938.

[2] B. Kilmer, C. Eibner, J. S. Ringel, and R. L. Pacula, "Invisible wounds, visible savings? using microsimulation to estimate the costs and savings associated with providing evidence-based treatment for PTSD and depression to veterans of operation enduring freedom and operation Iraqi Freedom," Psychol. Trauma Theory, Res. Pract. Policy, 2011, doi: 10.1037/a0020592.

[3] L. K. Cutting, Memory slips: A memoir of music and healing. HarperCollins, 1997

[4] S. Roth and M. J. Friedman, "Childhood trauma remembered: A report on the current scientific knowledge base and its applications," J. Child Sex. Abus., 1998, doi: 10.1300/J070v07n01_07.

[5] S. E. Taylor, Health psychology. Tata McGraw-Hill Education, 2006.

[6] W. Steele, "Trauma's Impact on learning and behavior: A case for interventions in schools," Trauma loss Res. Interv., vol. 2, no. 2, pp. $34-47,2002$

[7] M. A. Heller, Becoming incredible: Healing trauma through performance. The University of Utah, 2015.

[8] H. D. Brown, Principles of language learning and teaching, vol. 4. Longman New York, 2000

[9] M. Celce-Murcia and L. McIntosh, "Teaching English as a second or foreign language," 1991.

[10]J. Cuaresma, "Learning style preferences and academic performance of PHEM majors at the University of the Cordilleras," Unpubl. Undergrad. Thesis. Univ. Cordilleras, Baguio City, 2008.

[11]D. Utaminingsih, "Mapping And Developing Students Resilience In A Risk-Disaster Area." 